\title{
SYDNEY UNIVERSITY NATURAL RADIOCARBON MEASUREMENTS I
}

\author{
R. GILLESPIE*, H. A. POLACH**, and R. B. TEMPLE* \\ Department of Physical Chemistry, \\ The University of Sydney, Sydney, Australia
}

Preparations to establish a radiocarbon dating laboratory at the University of Sydney were made in 1970 in the Department of Physical Chemistry, to support Ph.D. studies and to supplement existing dating services in Australia to the archaeologic and geologic communities.

Liquid scintillation counting is used, with benzene synthesized by the method of Polach and Stipp (1967) as the counting liquid. Four ml benzene is mixed with $1 \mathrm{ml}$ AR toluene containing PPO and dimethyl POPOP to give final scintillant concentrations of $0.4 \mathrm{~g} / 1$ and $0.05 \mathrm{~g} / 1$ respectively (Tamers, 1965). Initially, a Philips scintillation spectrometer was used in the Pathology Department, University of Sydney. A single $20 \mathrm{ml}$ vial was employed alternating 1 to 3 day sample, background and modern standard determinations.

Recently the department acquired a Packard Model 2211 scintillation spectrometer, now set up specifically for natural radiocarbon measurements following the optimization, balance point, $5 \mathrm{ml}$ vial design and cycling procedures established at the ANU laboratory (Polach, 1969). Background count rate $\mathbf{B}$ for $5 \mathrm{ml}$ vials is ca. $4.1 \mathrm{cpm}$ and net oxalic acid standard count rate is ca. $31.1 \mathrm{cpm}$. Thus, the very favorable figure of merit $\mathrm{N}^{2} / \mathrm{B}=236$ ( $\mathrm{N}=$ net $0.95 \mathrm{NBS}$ oxalic) and $\mathrm{E}^{2} / \mathrm{B}=1480$ (counting efficiency $\mathrm{E}$ being ca. $78 \%$ ) is obtained.

Because $\mathrm{C}^{13} / \mathrm{C}^{12}$ ratios were not measured, best available estimates of their group mean values are based on carbon isotope distribution in nature as first established by Craig (1954). The estimated $\delta \mathrm{C}^{13}$ values used are listed and the $\delta \mathrm{C}^{13}$ corrected $\delta \mathrm{C}^{14}$ values, $\Delta$, are reported as parts per mil $(\%)$ observed deviation from 0.95 NBS oxalic acid standard (cf. Radiocarbon, editorial statement; Polach, 1969).

A series of previously dated samples has been run to check our preparation and counting technique (see Table 1a). For oxalic preparations, we used the wet $\mathrm{KMnO}_{4}$ oxidation method and compared our observed count rate with that obtained by the radiocarbon laboratories at the University of NSW and ANU, using the ANU Sucrose Standard as reference material. The agreement of all values (see Table 1b) indicates that very limited fractionation has occurred during our oxalic preparations and validates our results.

All ages are calculated using the Libby half-life of $5570 \pm 30$ years and 0.95 NBS oxalic modern standard with A.D. 1950 as refreence year. Errors quoted are one standard deviation based on counting statistics only. Thus the errors for samples counted on the Philips spectrometer

* Dept. of Physical Chemistry, University of Sydney, Sydney, Australia.

** Dept. of Geophysics and Geochemistry, and Dept. of Prehistory, Australian National University, Canberra. 
(SUA-1, 6-9, 11, 12) are larger than those counted on the Packard (SUA-13-18, MSO1, MSO2).

Sample pretreatment, unless otherwise specified, consists of careful visual inspection followed by dilute $\mathrm{HCl}$ and distilled water washings. If sufficient $\mathrm{CO}_{2}$ is not produced in a combustion or acid hydrolysis, the sample gas is diluted with cylinder $\mathrm{CO}_{2}$ of known activity. Such dilutions are indicated in the text.

\section{ACKNOWLEDGMENTS}

Our particular thanks go to J. Head, ANU Radiocarbon Laboratory, for tuition and supervision while R. G. Gillespie spent two months at the ANU Laboratory, and for assistance with the final age calculations; J. Gower, ANU Radiocarbon Laboratory, for setting up the Packard spectrometer; I. Fraser, Research Assistant, Dept. of Physical Chemistry, for assistance in construction of the benzene synthesis apparatus; and E. Smythe for determining sample activities on the Philips spectrometer. One of us (R.G.) is supported by a Commonwealth University Scholarship.

\section{SAMPLE DESCRIPTIONS}

I. CHECK SAMPLES

Table la

Interlaboratory check samples

\begin{tabular}{|c|c|c|c|c|}
\hline SUA no. & SUA date & Other lab. no. & Other date & Reference \\
\hline SUA-1 & $4780 \pm 230$ & Gak-834 & $4220 \pm 100$ & $\begin{array}{l}\text { Langford-Smith, } \\
\text { coll., pers. commun. }\end{array}$ \\
\hline SUA-6 & $1400 \pm 100$ & ANU-446 & $1490 \pm 80$ & $\begin{array}{l}\text { Polach, pers. } \\
\text { commun. }\end{array}$ \\
\hline SUA-7 & $27,030 \pm 2250$ & ANU-227 & $22,250 \pm 500$ & Polach et al. (1970) \\
\hline SUA-8 & $1540 \pm 100$ & ANU-207 & $1760 \pm 80$ & $\begin{array}{l}\text { Polach, pers. } \\
\text { commun. }\end{array}$ \\
\hline SUA-9 & $2030 \pm 115$ & ANU-263A & $2160 \pm 110$ & Polach et al. (1970) \\
\hline \multirow[t]{4}{*}{ SUA-13 } & $1150 \pm$ & ANU-538/1 & $980 \pm 70$ & $\begin{array}{l}\text { Polach, pers. } \\
\text { commun. }\end{array}$ \\
\hline & & ANU-538/2 & $1025 \pm 70$ & $\begin{array}{l}\text { Polach, pers. } \\
\text { commun. }\end{array}$ \\
\hline & & Gak-770 & $730 \pm 90$ & $\begin{array}{l}\text { Taylor, collector, } \\
\text { pers. commun. }\end{array}$ \\
\hline & & NSW-59 & $1040 \pm 60$ & $\begin{array}{l}\text { Carswell, pers. } \\
\text { commun. }\end{array}$ \\
\hline SUA-14 & $24,290 \pm 400$ & ANU-918 & $23,290 \pm 560$ & $\begin{array}{l}\text { Polach, pers. } \\
\text { commun. }\end{array}$ \\
\hline
\end{tabular}


Table la (continued)

\begin{tabular}{rccl}
\hline SUA no. SUA date & Other lab. no. & Other date & \multicolumn{1}{c}{ Reference } \\
\hline Gak-3438 & $21,400 \pm 250$ & $\begin{array}{l}\text { Langford-Smith, } \\
\text { coll., pers. commun. }\end{array}$ \\
NSW-60 & $25,800 \pm 900$ & $\begin{array}{l}\text { Carswell, pers. } \\
\text { commun. }\end{array}$
\end{tabular}

Comment: age determination cross checks between Australian labs were done on correctly proportioned batches of same sample pretreated by H.A.P.; Gak-770 and -3438 were done on another part of "same sample"; age differences are probably due to this factor or to different pretreatments. Otherwise there is excellent agreement between all labs.

Table $1 b$

ANU Sucrose Standard (uncorrected for $\delta \mathrm{C}^{13}$ ) w.r.t. 0:95 NBS oxalic (corrected for $\delta \mathrm{C}^{13}$ ) expressed as $\%$ Modern.

\begin{tabular}{llcll}
\hline SUA no. & SUA date & Other lab no. & Other date & Reference \\
\hline SUA-MS01 & $152.3 \pm 1.0$ & ANU-MS03 & $156.2 \pm 1.0$ & $\begin{array}{l}\text { Polach, pers. } \\
\text { commun. }\end{array}$ \\
SUA-MS02 & $154.6 \pm 1.0$ & ANU-MS04 & $157.5 \pm 1.0$ & $\begin{array}{l}\text { Polach, pers. } \\
\text { commun. }\end{array}$ \\
& ANU-MS05 & $155.1 \pm 1.0$ & $\begin{array}{l}\text { Polach, pers. } \\
\text { commun. } \\
\text { Carswell, pers. } \\
\text { commun. }\end{array}$
\end{tabular}

Comment: each independent determination of the activity of Sucrose is based on a $3000 \mathrm{~min}$. count with excellent agreement around a mean value of $154.75 \pm 1 \%$ Modern.

\section{GEOLOGIC SAMPLES}

SUA-11. Wollombi

$$
\begin{array}{r}
1820 \\
\text { A.D. } 130
\end{array}
$$

$\Delta=-203 \pm 19.0 \quad$ Est. $\delta C^{13}=-24.0 \pm 2.0 \%$ o

Wood charcoal from alluvial sediments of silt-clay in a tributary valley of Wollombi Brook, near Wollombi, N.S.W. (32 $53^{\prime}$ S Lat, $151^{\circ}$ $08^{\prime}$ E Long) exposed in a cut bank $2.5 \mathrm{~m}$ above present stream level. Coll. 1971 by K. J. Page, Geog. Dept., Univ. Sydney, as part of a series on chronology of tributary valley alluvial fills. Other samples in series have departmental code nos. $69 / \mathrm{C} / 16,70 / \mathrm{C} / 10$ and $70 / \mathrm{C} / 11 ; 69 / \mathrm{C} / 16$ dated at $4280 \pm 120$ в.P. (Kigoshi, pers. commun.).

\section{SUA-12. Kempsey}

$3010 \pm 240$

1060 в.C.

$$
\Delta=-312.1 \pm 9.7 \quad \text { Est. } \delta C^{13}=-2.0 \pm 2.0 \%
$$

Marine shells from top of spoil removed in construction of drainage 
ditch at Hat Head, near Kempsey, N.S.W. Sample and assoc. sediments suggest existence of sandy estuarine silt ca. $10 \mathrm{~m}$ below present surface. Coll. 1971 by B. Thom, Dept. Biogeog. and Geomorphol., A.N.U. (Dilution, 1000 min. count.) Comment (B.T.): indicates Recent age sediment transgresser by dunes, not related to Inner Barrier system.

\section{ARCHAEOLOGIC SAMPLES}

\section{Blue Mountains series}

Charcoal coll. 1971 by W. N. Holland and E. D. Stockton; subm. by Geog. Dept., Univ. Sydney. Dates are part of study on aboriginal occupation and climate in Blue Mountains area of N.S.W.

SUA-15. Leura

$12,550 \pm 144$

10,600 в.C.

$\Delta=-790.4 \pm 3.7 \quad$ Est. $\delta C^{13}=-24.0 \pm 2.0 \%$ o

Charcoal from Layer 9 to $18 \mathrm{~cm}$ below surface of cave at Lyre Bird's Dell, near Leura, N.S.W. (33 $43^{\prime} 30^{\prime \prime}$ S Lat, $150^{\circ} 20^{\prime}$ E Long). Assoc. with Capertian phase artifacts. (1300 min. count.)

\section{SUA-16. Hazelbrook}

Charcoal embedded in terrace alluvium 30 to $60 \mathrm{~cm}$ below surface

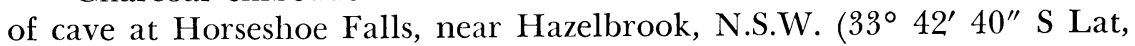
$150^{\circ} 27^{\prime} 30^{\prime \prime}$ E Long). Assoc. with Capertian phase artifacts. (Dilution, 1120 min. count.)

\section{SUA-17. Springwood}

$\begin{aligned} & \\ & \\ & 930 \pm 165 \\ & 980 \text { B.c. } \\ & \text { Est. } \delta C^{1 s}=-305.5 \pm 13.9 \quad-24.0 \pm 2.0 \%\end{aligned}$

Charcoal embedded in colluvium $46 \mathrm{~cm}$ below surface of cave adjacent to Springwood Creek, near Springwood, N.S.W. (33० $40^{\prime} 20^{\prime \prime} \mathrm{S}$ Lat, $150^{\circ} 35^{\prime} \mathrm{E}$ Long). Assoc. with Bondaian phase artifacts. This level, underlain by a sterile zone, marks basal limit of Bondaian culture (cf. SUA-18). (Dilution, 1040 min. count.)

SUA-18. Springwood

$6050 \pm 170$ 4100 B.c.

$\Delta=-529.3 \pm 9.7 \quad$ Est. $\delta C^{13}=-24.0 \pm 2.0 \%$

Charcoal embedded in colluvium $76 \mathrm{~cm}$ below surface of cave adjacent to Springwood Creek, near Springwood, N.S.W. $\left(33^{\circ} 40^{\prime} 20^{\prime \prime} \mathrm{S}\right.$ Lat, $150^{\circ} 35^{\prime}$ E Long). Assoc. with Capertian phase artifacts. This level, overlain by a sterile zone, marks upper limit of Capertian culture (cf. SUA-17). (Dilution, 1040 min. count.)

General Comment (W.N.H.): these dates, with others from same area (Stockton and Holland, ms. in preparation) suggest a break in occupation between Bondaian and Capertian phases thought to be assoc. with a coincidental deterioration of climatic conditions in this area. 


\section{REFERENCES}

Craig, Harmon, 1954, Carbon 13 in plants and the relationships between Carbon 13 and Carbon 14 variations in nature: Jour. Geology, v. 62, p. 115-149.

Polach, H. A., 1969, Optimization of liquid scintillation radiocarbon age determinations and reporting ages: Atomic energy in Australia, v. 12, p. 21-28.

Polach, H. A., Lovering, J. F., and Bowler, J. M., 1970, ANU radiocarbon date list IV: Radiocarbon, v. 12, p. 1-18.

Polach, H. A. and Stipp, J. J., 1967, Improved synthesis techniques for methane and benzene radiocarbon dating: Jour. Applied Radiation and Isotopes, v. 18, p. 359-364.

Tamers, M. A., Routine carbon-14 dating using liquid scintillation technique: Radiocarbon and tritium dating, 6th Internatl. Conf. Proc., Pullman, Washington, p. 53-67. 